\title{
NEW DATA FOR ANTHOINITE
}

\author{
Th. G. Sahama ${ }^{1}$, Oleg v. Knorring ${ }^{2}$ \\ and Mart'ti Lehtinen ${ }^{1}$ \\ ${ }^{1}$ Dept. of Geology, University of Helsinki, Finland \\ ${ }^{2}$ Dept. of Earth Sciences, Leeds University, U. K.
}

\begin{abstract}
Based on electron microscopy, electron diffraction data and the flat layer specimen technique applied in clay mineralogy, the X-ray powder pattern of anthoinite was indexed and the unit cell parameters were calculated. The mineral is triclinic (pseudomonoclinic) with $a_{o}=9.51 \AA, b_{o}=9.23 \AA, c_{o}=13.05 \AA, \alpha=93^{\circ} 20^{\prime}, \beta=120^{\circ} 00^{\prime}, \gamma=88^{\circ} 20^{\prime}$, $V=990 \AA^{3}$. Single crystals of the mineral suitable for X-ray work have not been found. Density 5.06. Thermobalance run (speed $10^{\circ} \mathrm{C} / \mathrm{min}$.) expels all water at one step at $400^{\circ}-545^{\circ} \mathrm{C}$. The temperature of dehydration suggests the presence of $\mathrm{OH}$ rather than $\mathrm{H}_{2} \mathrm{O}$ in the structure. Two new chemical analyses are given confirming the composition $\mathrm{AlWO}_{3}$ $(\mathrm{OH})_{3}$. The number of anions in the unit cell is $60 . Z=10$ for the formula given. The perfect cleavage suggests a crystal structure displaying sheets parallel to 001 .
\end{abstract}

\section{Introduction}

The mineral anthoinite was discovered from the tungsten locality of Mt. Misobo in the Congo by Varlamoff (1947). He described the mode of occurrence of the mineral and arrived at the conclusion that anthoinite probably represents an alteration product of scheelite or wolframite or both and has been partly replaced by later ferberite. He summarized the results of the chemical analyses available which conform with the bulk composition $\mathrm{Al}_{2} \mathrm{O}_{3} \cdot 2 \mathrm{WO}_{3} \cdot 3 \mathrm{H}_{2} \mathrm{O}$. In addition to the type locality, the mineral was reported from some other tungsten mines in the Maniema District in the Congo and from the Kifurwe region in Rwanda.

On the basis of the specimens obtained from Varlamoff, Niggli and Jäger (1957) supplied additional data for the mineral. They gave the
X-ray powder pattern, made a differential thermal analysis and an electron microscopic study. Based on electron diffraction data they suggested that the mineral is monoclinic or possibly triclinic. No other data for the mineral are known to the authors. No single crystals suitable for X-ray study have been found. The mineral occurs as fine-grained pulverulent masses only.

It is now known that anthoinite occurs in most - if not in all-localities of ferberite mineralization in the Kigezi District (S. W. Uganda), in Rwanda and in the Kivu Province (Congo). Pseudomorphic masses of pure anthoinite beautifully exhibiting the form $\{011\}$ of scheelite have been collected, e.g., from the Bugarama Mine in Rwanda. No occurrence of the mineral outside Central Africa has been reported. 
On several occasions, the first two authors have collected a number of specimens of the tungsten minerals from some of the mines in Kigezi and in Rwanda. The specimens have been subjected to closer study. This paper deals with the refinement of the data for anthoinite only.

\section{Electron microscopy}

The grain size (less than $2 \mu$ ) of the anthoinite material available was too small for optical microscopic study. Fig. 1 presents the typical habit of the mineral as revealed by electron microscopy. The observations reported by Niggli and Jäger ( $o p$. cit.) were essentially confirmed. Anthoinite exhibits one strongly pronounced cleavage plane which causes virtually all the grains to rest on that plane. The crystal flakes show two subvertical faces (cleavage planes?). The angle between these two faces can be measured only approximately from the electron micrographs. The values obtained, viz., $85^{\circ}$ and $95^{\circ}$, respectively, should be taken with some reservation.

Because of the perfect cleavage, electron diffraction photographs could be obtained only of a section representing the cleavage plane. Fig. 2 illustrates the pattern on that plane and is reproduced in the same orientation as Fig. 1. The pattern of Fig. 2 displays two reciprocal cell rows perpendicular to each other. Taking the cleavage plane arbitrarily as the basal pinacoid, the two reciprocal cell rows in Fig. 2

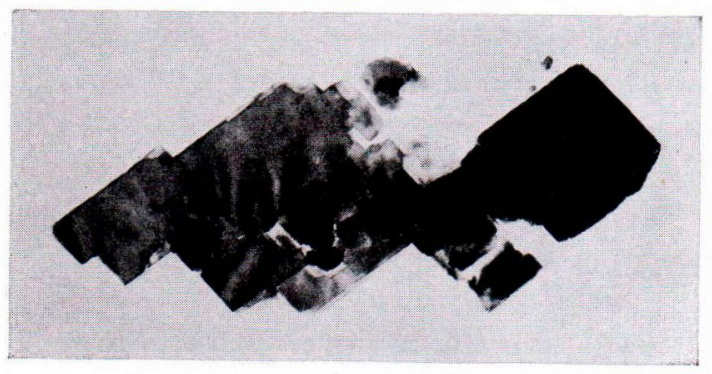

Fig. 1. Electron micrograph of anthoinite. Nyamulilo Mine, Kigezi, Uganda. $50000 \mathrm{X}$.

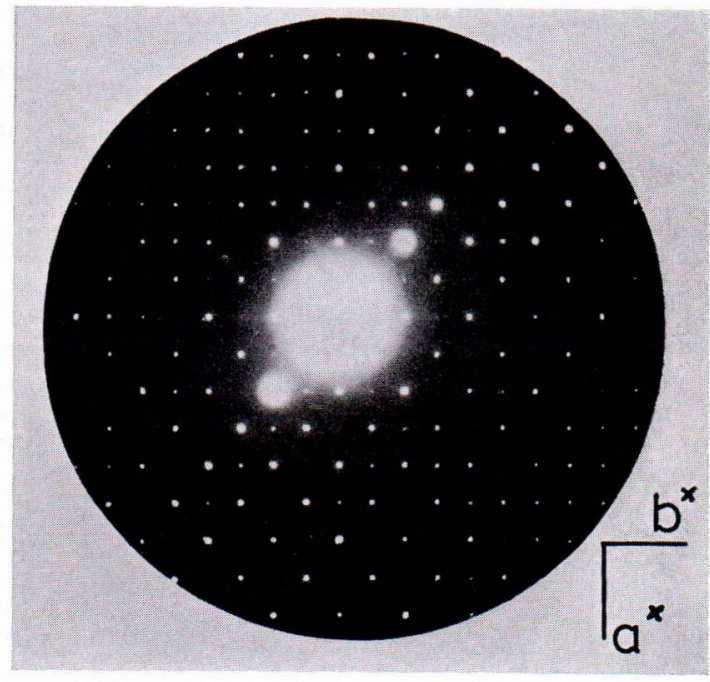

Fig. 2. Electron diffraction photograph of the anthoinite of Fig. 1.

would represent $a^{*}$ and $b^{*}$, respectively, with $\gamma^{*}=90^{\circ}$. Then the subvertical faces of Fig. 1 would display the traces of the prism faces (110) and $(1 \overline{1} 0)$. Using the powder pattern of a $\mathrm{TlCl}$ coating as an internal standard on the electron diffraction photograph (not shown in Fig. 2), approximate numerical values for $a^{*}$ and $b^{*}$ could be obtained.

\section{Determination of $c^{*}$}

The reciprocal cell translation $c^{*}$ was determined using the flat layer specimen technique commonly employed in clay mineralogy. A small batch of the purified anthoinite material was ground to fine powder and treated with an ultrasonic cleaner. A glass plate was placed in the suspension and the material was allowed to settle. In the anthoinite coating on the glass thus obtained the grains will preferably rest on the cleavage plane. The glass plate was mounted in the Philips Norelco diffractometer and the $\mathrm{X}$-ray powder pattern was recorded. The preferred orientation in the sample causes an increase of the intensity of the reflections of the 
TABle 1.

X-ray powder pattern of anthoinite. Nyamulilo Mine, Kigezi, Uganda. The lines marked with an asterisk are considered unequivocal.

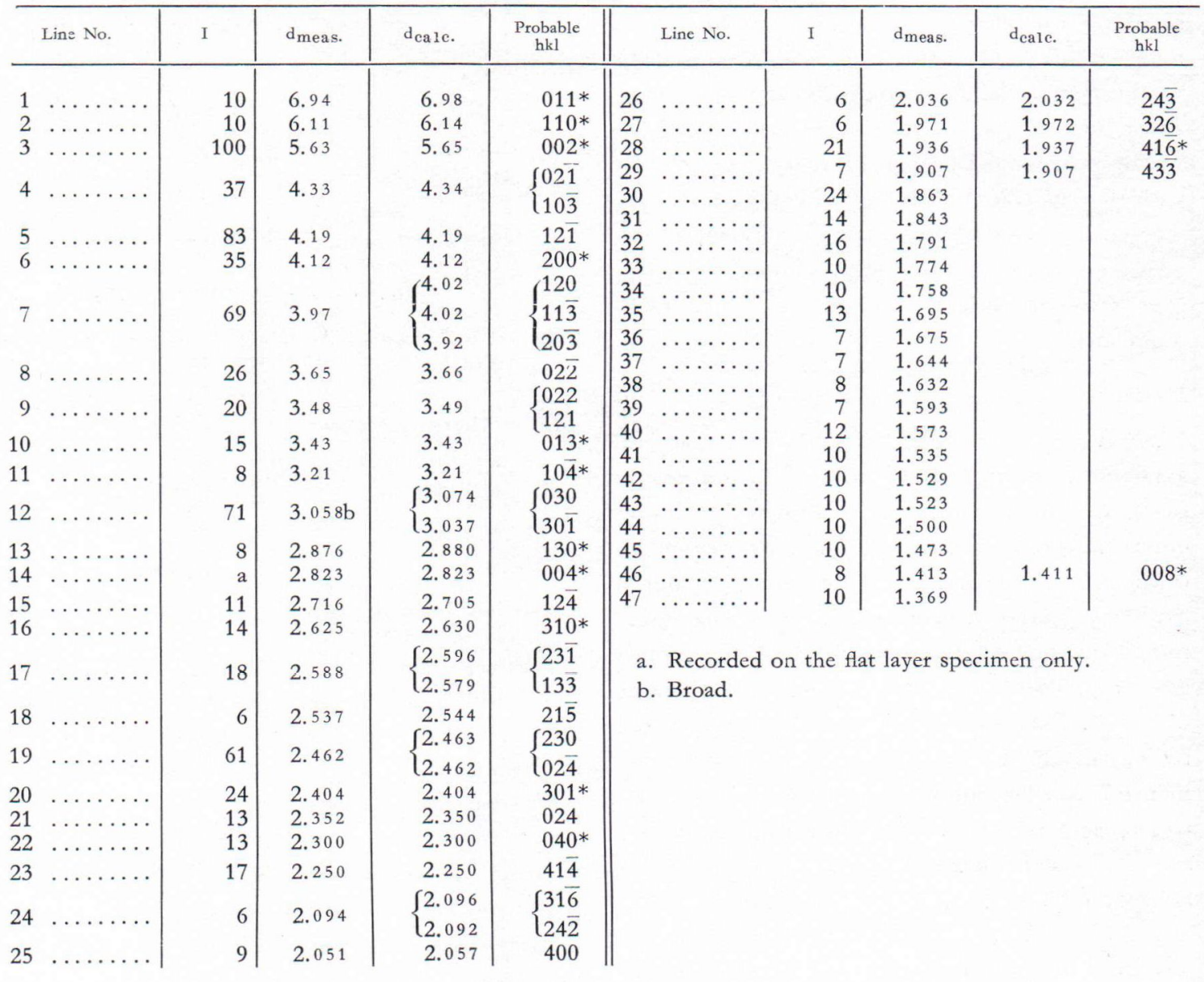

supposed type 00l. Compared with the powder pattern of an ordinary specimen, the lines Nos. 3, 14 and 46 (Table 1) were strongly increased in intensity. The numerical value for $c^{*}$ was calculated from the Q-values for these lines.

\section{X-ray powder pattern}

The values for $a^{*}, b^{*}, c^{*}$ and $\gamma^{*}$ being known in a first approximation, those for $\alpha^{*}$ and $\beta^{*}$ were estimated using Ito's procedure. The indexing of the powder pattern (Table 1) was calculated and the unit cell dimensions refined at the Government Computing Center in Hel- sinki. The agreement between the measured and the calculated $d$-values is reasonably good. The indexing of several lines is, however, not unequivocal. This circumstance is caused by the relatively large unit cell translations and by the small difference between the values for $a_{0}$ and $\mathrm{b}_{0}$. For the lines with low $d$-values the indexing becomes meaningless. The triclinic unit cell dimensions obtained are:

$$
\begin{array}{rlrl}
\mathrm{a}_{\mathrm{o}} & =9.51 \AA & \alpha & =93^{\circ} 20^{\prime} \\
b_{\mathrm{o}} & =9.23 & \beta & =120^{\circ} 00^{\prime} \\
c_{\mathrm{o}} & =13.05 & \gamma & =88^{\circ} 20^{\prime} \\
V=990 \AA^{3} &
\end{array}
$$


The uncertainties connected with these unit cell parameters are difficult to estimate on the basis of the powder pattern. The following values seem reasonable: $\pm 0.01 \AA$ for the three axial lengths and $\pm 10^{\prime}$ for the axial angles. The verification of the unit cell parameters given must await single crystal $\mathrm{X}$-ray data.

The powder pattern of Table 1 agrees closely with that tabulated by Niggli and Jäger (op. cit.). The differences between the two powder patterns are restricted to weak lines and are possibly caused by the difference in the recording technique used.

\section{Density}

Because the fine-grained anthoinite material available was more or less porous, an immersion of a piece of it in water or in some other liquid could expectedly yield a low value for the density of the mineral. Therefore, the Bugarama material (Table 2) was ground and the density was determined on the powdered sample with the Notari gas volumeter. The result $\mathrm{d}=5.06 \pm 0.1$ was obtained. This value is higher than that reported by Varlamoff ( $\mathrm{d}=$ ca. 4.6 ; op. cit.). He does not mention the method of determination used.

The density calculated for the two anthoinite specimens of Table 2 is $d=5.17$. The calculation is based on $\mathrm{O}+\mathrm{OH}=60$ in the unit cell.

\section{Thermal behavior}

The Bugarama mineral was studied with the thermobalance using a heating rate of $10^{\circ} \mathrm{C} / \mathrm{min}$. Fig. 3 illustrates the weight loss plotted against temperature. After the initial expulsion of the secondary moisture adhered in the finely powdered sample, the total water content of $9 \%$ (Table 2) is expelled at one single step at a temperature range of $400^{\circ}-545^{\circ} \mathrm{C}$. The result of the thermobalance run agrees with the DTA data published by Niggli and Jäger (op. cit.). These authors found a pronounced endothermic reaction indicated by a minimum in the DTA curve at $515^{\circ} \mathrm{C}$. They interpreted this reaction as due to the expulsion of the hydroxyl ions. The shape

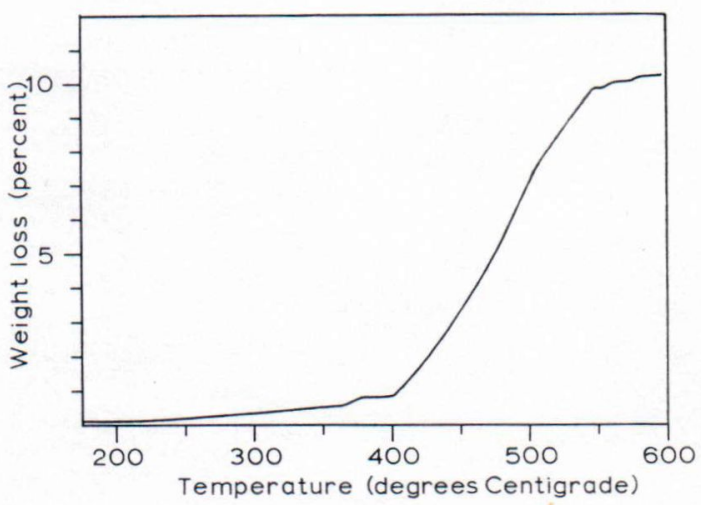

Fig. 3. Thermobalance run of anthoinite from the Bugarama Mine, Rwanda.

of the thermobalance curve of Fig. 3 and the relatively high temperature of dehydration suggests that all water is present as $\mathrm{OH}$ rather than as $\mathrm{H}_{2} \mathrm{O}$ in the structure.

\section{Chemical composition}

Two specimens of anthoinite, from the Nyamulilo (Kigezi, Uganda) and Bugarama (Rwanda) Mines, respectively, were subjected to chemical analysis (Table 2). The Nyamulilo material contained some quartz, mica and tourmaline which were removed by centrifuging in Clerici solution. The Bugarama material was seemingly free from contamination. The purities of both materials were tested under the binocular microscope. The small amounts of $\mathrm{SiO}_{2}$ shown in Table 2 are caused by traces of quartz left. In addition to the results of the original analyses, the table also reproduces the compositions of the two anthoinite specimens free from contamination and recalculated to one hundred percent.

The chemical compositions of the two anthoinite specimens reproduced in Table 2 are very similar to that of the anthoinite from the type locality of Mt. Misobo (Varlamoff, op. cit.). According to Varlamoff, the ferric iron shown by some of the Mt. Misobo anthoinite analyses represents merely a contamination. If the ferric iron of the Nyamulilo anthoinite is considered a contamination, then the compositions of the two 
TABLE 2.

Chemical composition of anthoinite.

New analyses by O. v. Knorring.

\begin{tabular}{|c|c|c|c|c|}
\hline & \multicolumn{2}{|c|}{$\begin{array}{l}\text { Nyamulilo Mine, } \\
\text { Kigezi, Uganda. }\end{array}$} & \multicolumn{2}{|c|}{$\begin{array}{c}\text { Bugarama Mine, } \\
\text { Rwanda. }\end{array}$} \\
\hline & $\begin{array}{l}\text { Original } \\
\text { analysis } \\
\%\end{array}$ & $\begin{array}{c}\text { Calculated } \\
\text { to } \\
100 \%\end{array}$ & $\begin{array}{c}\text { Original } \\
\text { analysis } \\
\%\end{array}$ & $\begin{array}{c}\text { Calculated } \\
\text { to } \\
100 \%\end{array}$ \\
\hline $\mathrm{WO}_{3}$ & 72.90 & 73.42 & 74.84 & 74.84 \\
\hline $\mathrm{SiO}_{2}^{\circ} \ldots \ldots$ & 0.24 & 一 & 0.08 & - \\
\hline $\mathrm{TiO}_{2} \ldots$. & n.d. & 一 & n.d. & - \\
\hline $\mathrm{Al}_{2} \mathrm{O}_{3} \ldots$ & 15.82 & 15.93 & 16.03 & 16.03 \\
\hline $\mathrm{Fe}_{2} \mathrm{O}_{3} \ldots$ & 1.74 & 1.75 & 0.07 & 0.07 \\
\hline $\mathrm{MgO} \ldots$. & n.d. & - & n.d. & - \\
\hline $\mathrm{CaO} \ldots \ldots$ & n.d. & - & n.d. & - \\
\hline $\mathrm{H}_{2} \mathrm{O}+\ldots$ & 8.84 & 8.90 & 9.06 & 9.06 \\
\hline $\mathrm{H}_{2} \mathrm{O}-\cdots$ & 0.22 & - & 0.06 & - \\
\hline Total & 99.76 & 100.00 & 100.14 & 100.00 \\
\hline
\end{tabular}

n.d. = not detected.

Unit cell content based on $\mathrm{O}+\mathrm{OH}=60$.

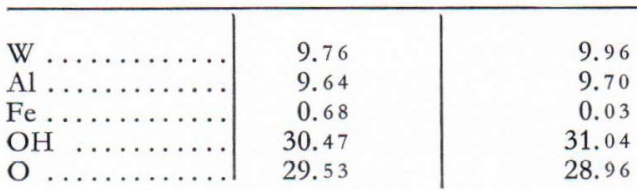

anthoinite specimens of Table 2 virtually match each other. The color of the Nyamulilo material is slightly yellowish whereas that of the Bugarama material is white.

The unit cell contents of the Nyamulilo and Bugarama anthoinite specimens were calculated from the cell volume, density and chemical composition. The number of anions $(\mathrm{O}+\mathrm{OH})$ obtained is not far from 60 and can be brought up to that figure by using a density value close to its upper limit as indicated by the uncertainty given. Therefore, it is felt justified to give the unit cell contents on the basis of $\mathrm{O}+\mathrm{OH}=60$ (Table 2). Taking the water as $\mathrm{OH}$, the formula of the mineral can be written $\mathrm{AlWO}_{3}(\mathrm{OH})_{3}$ with $Z=10$.

The pronounced cleavage exhibited by the mineral would suggest a crystal structure displaying sheets parallel to 001 .

Acknowledgements - The authors are indebted to $\mathrm{Mr}$. M. Eerola (thermobalance run), Mr. M. Kataja (computer work) and Mr. R. Räty (electron microscopy).

\section{REFERENCES}

Niggli, ErnSt und Jäger, Emilie (1957) Untersuchungen an Anthoinit. Neues Jb. Mineral. Abh., Bd. 91, S. 35 .
VarlamofF, N. (1947) Anthoinite, nouveau tungstate hydraté d'alumine. Ann. Soc. Géol. Belgique, T. 70, p. B153.

Manuscript received, November 26, 1969. 